\title{
Free-living nematodes affect oxygen turnover of artificial diatom biofilms
}

\author{
M. Mathieu ${ }^{1}$, J. Leflaive ${ }^{1}$, L. Ten-Hage ${ }^{1}$, R. de Wit ${ }^{2}$, E. Buffan-Dubau $^{3, *}$ \\ ${ }^{1}$ Laboratoire d'Ecologie Fonctionnelle (ECOLAB), UMR 5245 CNRS/UPS/INPT, Université Paul Sabatier, bât. 4R3, \\ 118 route de Narbonne, 31062 Toulouse Cedex 4, France \\ ${ }^{2}$ UMR 5119 CNRS - Université Montpellier I-Ifremer 'Ecosystèmes lagunaires', Université Montpellier II, Case 093, \\ Place Eugène Bataillon, 34095 Montpellier Cedex 05, France
}

${ }^{3}$ Laboratoire d'Ecologie Fonctionnelle (ECOLAB) UMR 5245 CNRS/UPS/INPT, Université Paul Sabatier, 29 Rue Jeanne Marvig, 31055 Toulouse Cedex 9, France

\begin{abstract}
The aim of the present study was to examine the effects of biofilm-dwelling nematode activity on the oxygen turnover of cultured diatom biofilms. Oxygen microprofiles were simultaneously measured using the microelectrode technique in biofilms incubated with and without nematodes during short-term $(24 \mathrm{~h})$ and medium-term $(6 \mathrm{~d})$ experiments. During $24 \mathrm{~h}$ nycthemeral incubations, maximum oxygen concentrations and oxygen peak depths of microprofiles, as well as net oxygen production rates, were significantly higher in the diatom biofilms with nematodes. These effects might be dependent on the densities of nematodes. In the present study, significant effects were observed at nematode densities exceeding 100 ind. $\mathrm{cm}^{-2}$, but not at a density $<50$ ind. $\mathrm{cm}^{-2}$. During $6 \mathrm{~d}$ incubations, net oxygen production in the photic zone was significantly higher in biofilm containing meiofauna than in biofilms without meiofauna. The processes involved are discussed. The short-term experiment simulates a disturbance of a lotic diatom biofilm as would be induced by a sudden colonisation of nematode populations. The question remains whether a long-term occurrence of nematodes in the biofilm would also result in an increased productivity rate. A first indication of a persistent increase in net productivity related to the continuous presence of nematodes is provided by the $6 \mathrm{~d}$ incubation experiment.
\end{abstract}

KEY WORDS: Diatom biofilms $\cdot$ Nematodes $\cdot$ Oxygen microprofile $\cdot$ Microelectrode $\cdot$ Oxygen community metabolism $\cdot$ Net production rate $\cdot$ Grazing $\cdot$ Bioturbation

\section{INTRODUCTION}

In the littoral zones of streams, microbial communities often form epilithic biofilms covering gravel sediments (Biggs 1995). Microbial biofilms substantially contribute to hydrodynamic, biogeochemical and physical processes of running waters (Battin et al. 2003). Epilithic biofilm biomass comprises, on average, $>30 \%$ of the microalgae (Peterson 1996), constituting the basis of the benthic food web in such ecosystems (Liess \& Hillebrand 2004). The growth of microbial biofilms increases the retention rates of both stream water detained in quiescent zones and suspended particles (Battin et al. 2003). This may confer upon these biofilms the role of a safe habitat, in which invertebrates are protected against drifting.

Meiofauna represent the invertebrates passing through a mesh of $1000 \mu \mathrm{m}$, but retained on one of $63 \mu \mathrm{m}$, and their analysis requires specialized methods and taxonomic competence (Robertson et al. 2000). These meioinvertebrates are abundant in streams (Hakenkamp \& Morin 2000) and are found inhabiting river biofilms (Sabater et al. 2003). Due to their high production/biomass ratio, they may contribute substantially to benthic secondary production (Stead et al. 2005). Many meiofauna are consumers of benthic microalgae (Hann 1991, Borchardt \& Bott 1995, Bott \& Borchardt 1999) and serve as a food source for a 
variety of stream macroinvertebrates, as well as larval and juvenile fishes (Sibert et al. 1977, Schmid-Araya \& Schmid 2000). A recent study has shown their importance as intermediates in stream food webs (SchmidAraya et al. 2002). Despite their potential functional importance in stream food webs, the interactions between biofilm-inhabiting meiofauna and the attached microbial communities have been poorly documented (Hakenkamp \& Morin 2000, Sabater et al. 2003). To our knowledge, only 1 study has addressed interactions between freshwater biofilms and a major group of meiofaunal organisms, examining the attractant and repellent effects of cyanobacterial odor compounds on biofilm-inhabiting nematodes (Höckelmann et al. 2004).

Growth and architecture of microalgal biofilms in aquatic environments are often constrained by the availability of both light (Hill 1996) and nutrients (nitrogen and phosphorus; Hillebrand \& Sommer 1997), and by consumption from grazers (Liess \& Hillebrand 2004). The grazing effect of the larger size classes (macrofauna such as gastropods, insect larvae, herbivorous fish, mayflies) on biomass, diversity, composition, heterogeneity and production of microalgal biofilms has previously been investigated (Liess \& Hillebrand 2004, Alvarez \& Peckarsky 2005). It is known that macrograzers such as gastropods may stimulate production of attached microalgal communities (Kaehler \& Froneman 2002). In contrast, previous studies of the effect of smaller metazoans (meiofauna) are rare. Information is mainly limited to the interactions between meiofaunal crustaceans, oligochaetes and chironomid larvae and algal biomass (Hann 1991, Lawrence et al. 2002). Meiofaunal activity (bioturbation, grazing and excretion) is thought to stimulate microbial metabolism and nutrient transport in marine systems (Hakenkamp \& Morin 2000). Obviously, meiofauna may have a similar effect in streams. Sabater et al. (2003) highlight that the link between cyanobacterial dynamics and meiofauna inhabiting the mats may be essential in the processes of the diffusion of unpleasant odorous metabolites (e.g. geosmin) into the river water. It has been hypothesized that meiofaunal nematodes affect mat communities through bioturbation and grazing (Höckelmann et al. 2004). There is yet little evidence for these hypotheses. Free-living nematodes regularly dominate meiofaunal communities of lotic habitats (Traunspurger 2000). However, to our knowledge, no previous study has investigated the effect of nematode activity on mat communities, and whether and how they may influence the structure and function of river biofilms remains a matter of debate (Traunspurger 2000, Höckelmann et al. 2004).

The present study aimed to experimentally examine the effect of biofilm-dwelling nematode assemblages on the vertical microdistribution and the production and consumption rates of oxygen in diatom biofilms. Microelectrode techniques were used to measure oxygen microprofiles, which are linked to physicochemical processes and the phototrophic and heterotrophic activities of oxygenic microbial communities in microbial biofilms (e.g. Glud et al. 1992, Epping et al. 1999).

\section{MATERIALS AND METHODS}

Cultivation of diatom biofilms. Biofilms were cultivated using 2 diatom strains, Nitzschia palea and Fistulifera saprophila, isolated from epilithic biofilm sampled in the Tarn River (France). The strains were maintained in liquid combo medium (Kilham et al. $1998)$ at $18^{\circ} \mathrm{C}$ and $45 \mu \mathrm{mol}$ photons $\mathrm{m}^{-2} \mathrm{~s}^{-1}(16: 8 \mathrm{~h}$ light:dark). Aliquots of $30 \mathrm{ml}$ dense diatom cultures were centrifuged for $10 \mathrm{~min}$ at $3000 \times g$ to remove medium and then resuspended in $5 \mathrm{ml}$ of new medium. Then, $0.8 \mathrm{ml}$ aliquots of $1.5 \%$ agar combo medium were added to each well ( $2 \mathrm{~cm}^{2}$ area) of a 24 -well plate, in order to provide a soft substratum allowing both the growth of biofilms and, later, the introduction of microelectrodes in biofilms without any risk of breakage (see 'Microsensor measurements and oxygen flux calculations' below). In each well, the agar medium was covered with $1 \mathrm{ml}$ aliquots of a concentrated algal culture (monospecific biofilm). For biofilms cultivated from the 2 diatom species, concentrated aliquots of the 2 strains were mixed in 1:1 proportion $(\mathrm{v} / \mathrm{v})$, and the agar medium was covered with a $1 \mathrm{ml}$ aliquot of the concentrated algal mix. These inoculated plates were incubated under the same conditions as the stock cultures for 3 to $4 \mathrm{wk}$ before starting experiments. Within $3 \mathrm{wk}$ the diatoms formed a dense and cohesive biofilm, which was free of meiofauna.

Extraction of biofilm-dwelling meiofauna. The freshwater meiofaunal assemblage was extracted from epilithic phototrophic biofilms growing on a natural shingle layer, in an experimental laboratory channel flow of natural river water (Garonne, France), under ambient light and temperature $\left(20\right.$ to $\left.30^{\circ} \mathrm{C}\right)$ and with a flow velocity of $0.30 \mathrm{~m} \mathrm{~s}^{-1}$ for approximately 4 mo. Living nematodes were extracted according to the principle of the Baermann Funnel extraction (Hodda \& Eyualem-Abebe 2006). Biofilm samples were suspended on a nematode permeable filter (100 $\mu \mathrm{m}$ mesh sieves) above a filtered natural water reservoir. This system allowed migration of meiofauna from biofilm samples to water through sieve meshes. Meiofaunal samples were then concentrated by sieving through $50 \mu \mathrm{m}$ meshes, which were then transferred to filtered natural water $(50 \mu \mathrm{m})$ and stored for a few hours before starting the experiments. Living nematodes were hand- 
picked under a stereoscopic microscope, rinsed in filtered natural water and transferred to the $\mathrm{N}$-diatom biofilms (see 'Short-term $(24 \mathrm{~h})$ experiment' and 'Six day incubation experiment' below) at the beginning of each experiment $\left(T_{0}\right)$.

Microsensor measurements and oxygen flux calculations. Oxygen concentration microprofiles were measured in cultivated diatom biofilms using a UNISENSE profiling module equipped with 2 Clarktype $\mathrm{O}_{2}$ microelectrodes (50 $\mu$ m outside diameter) and a computer-controlled micromanipulator (Revsbech 1989). Two-point calibrations were performed using the procedure described by Revsbech et al. (1983). Oxygen partial pressures were converted to concentrations as a function of conductivity and temperature (Garcia \& Gordon 1992). The $100 \mu \mathrm{m}$ vertical spatial resolution of oxygen concentration profiles was determined according to Revsbech et al. (1983), taking into account both the oxygen diffusion rate in biofilms as well as the external diameter of microelectrodes. The net oxygen community metabolism of the diatom biofilm was calculated for each oxygen profile according to Kühl et al. (1996). The flux of oxygen between the biofilm and the overlying water was calculated from the oxygen profile in the diffusion boundary layer according Fick's diffusion law (a positive sign of this flux indicated a flux from the biofilm to the water column and a negative sign indicated a flux from the water to the biofilm). The microelectrode was introduced from above, and it has been shown that this procedure results in a slight compression of the diffusion boundary layer thickness and, concurrently, in an overestimation of the mass transfer flux between the biofilm and the overlying water compared to a non-disturbed situation (Glud et al. 1994). Unfortunately, it was not possible to introduce the microelectrode from below as recommended by these authors. Nevertheless, this overestimation introduced a relative error of the net rate estimations in both the control and the treatment. Hence, despite this small artefact, our method clearly allows us to detect differences between the treatment and the control and thus to study the effect of nematodes on the oxygen community metabolism of the biofilms. We also calculated a flux of oxygen between the bottom layer of the biofilm (1.5 to $4 \mathrm{~mm}$ depth depending on the biofilm studied) and the lower agar layers using Fick's diffusion law adapted for sediments assuming a microbial biofilm porosity of 0.95 (Wieland et al. 2001). The instantaneous fluxes of oxygen across both interfaces were multiplied by 10 min (interval between successive measurements) and summed up to calculate a net areal day and night time oxygen community metabolism of the biofilm, with a positive sign indicating net production and a negative sign indicating net consumption. For the short-term (24 h) experiment, microprofiles were resolved at 1 spot in each biofilm and the amounts were expressed as mean rates by dividing the amount by the total duration (in minutes) of the day and night time periods, respectively.

Short-term (24 h) experiment. This experiment was designed to examine the influence of nematode activity on nycthemeral oxygen dynamics in cultivated diatom biofilms with a naturally fluctuating light intensity. Therefore, we monitored the oxygen profiles at single spots in the biofilms and replicated these observations in pairs during 3 successive $24 \mathrm{~h}$ nycthemeral incubation periods (Periods 1, 2 and 3) in July 2005, using $3 \mathrm{wk}$ old diatom monospecific biofilms (Nitzschia palea) free of meiofauna (Fig. 1). At the beginning of each incubation period $\left(T_{0}\right), 1$ cultivated biofilm was amended with 600 living nematodes (N-biofilm), while a control biofilm was not amended (C-biofilm). These $\mathrm{N}$ - and C-biofilms were incubated for $24 \mathrm{~h}$ under attenuated natural light conditions using an exposed position in the laboratory facing an eastern window. The incident light and temperature were monitored in the overlying water with a Li-Cor 189 probe and a Tynitag thermometer, respectively. Light intensity ranged from 0 to $350 \mu \mathrm{mol}$ photons $\mathrm{m}^{-2} \mathrm{~s}^{-1}$ (maximum during the morning periods around 09:00 h), and temperature ranged from 22 to $30^{\circ} \mathrm{C}$ for each $24 \mathrm{~h}$ nycthemeral period. Each pair of C- and N-biofilms was submitted to equivalent natural light intensities and temperatures (Fig. 2). Vertical oxygen microprofiles were measured

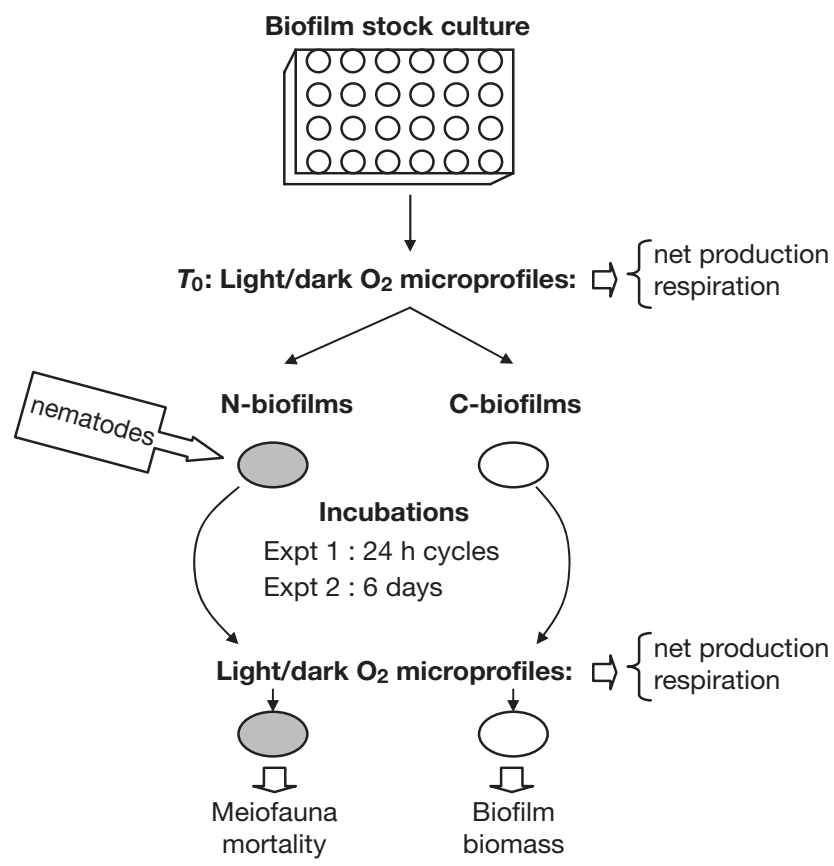

Fig. 1. Experimental designs of both the short-term $(24 \mathrm{~h})$ and medium-term ( $6 \mathrm{~d}$ ) experiments. $T_{0}$ : beginning of incubation period; N-biofilm: with nematodes; $\mathrm{C}$-biofilm: without meiofauna 

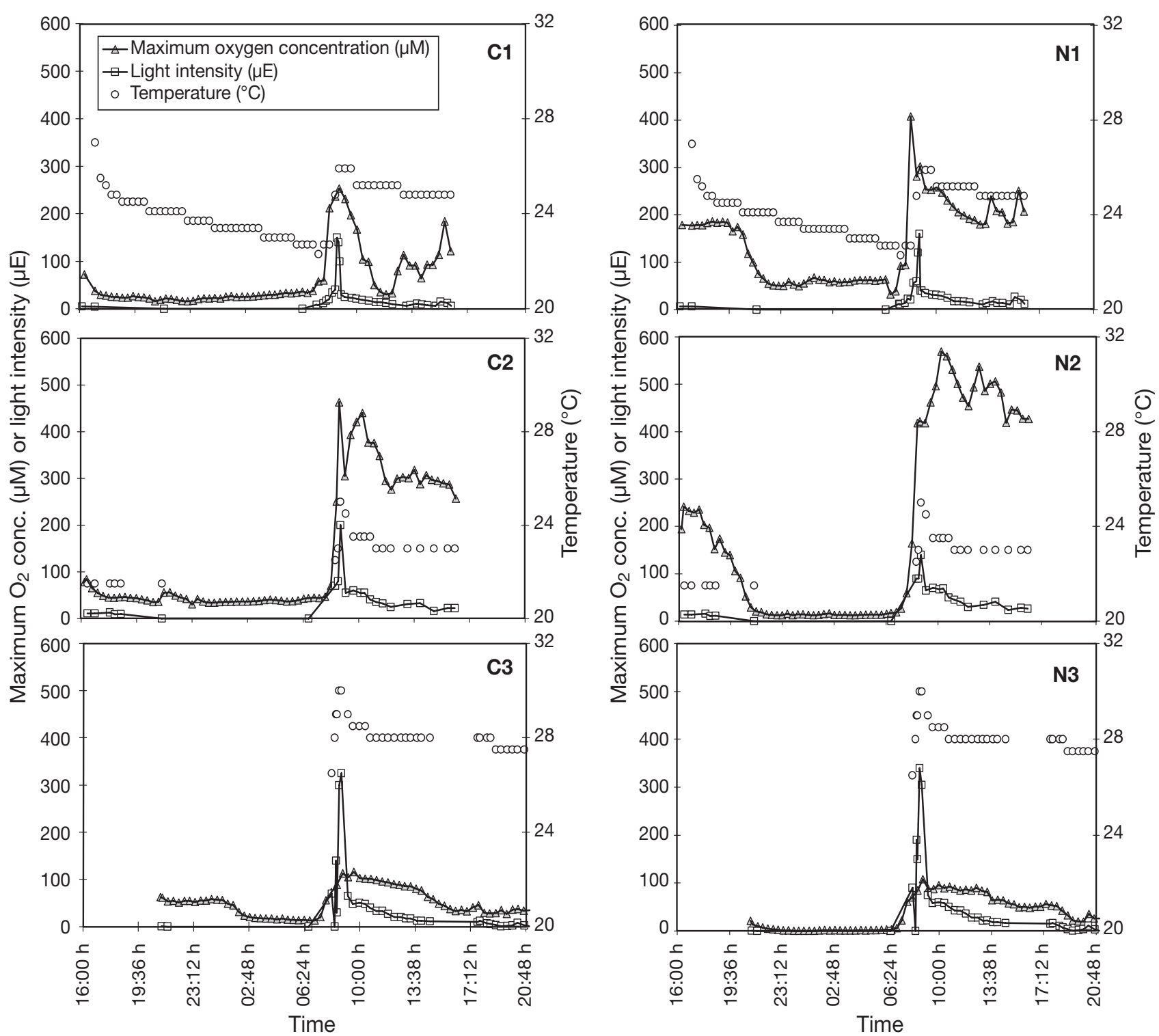

Fig. 2. Short-term $(24 \mathrm{~h})$ experiment. Nycthemeral light intensity, temperatures and maximum oxygen concentrations of microprofiles, measured during the $24 \mathrm{~h}$ nycthemeral incubation periods (1, 2 and 3), simultaneously in both N-biofilms (with nematodes) and C-biofilms (without meiofauna)

in parallel in the $\mathrm{N}$ - and $\mathrm{C}$-biofilms every $10 \mathrm{~min}$, using 2 oxygen microelectrodes operated from a single micromanipulator. The micromanipulator was maintained at the same position in the horizontal plane during the $24 \mathrm{~h}$ period, which allowed us to monitor the profiles at fixed measurement spots in both the $\mathrm{N}$ - and $\mathrm{C}$ biofilms. Microprofiles were resolved at 1 spot each in $\mathrm{N}$ - and C-biofilms during a $24 \mathrm{~h}$ incubation. On the whole, during the 3 successive incubation periods, microprofiles were resolved at 6 spots in 6 diatom biofilms from 6 multi-well plates. The net oxygen metabolism rates of the biofilm were integrated over the $24 \mathrm{~h}$ period (day net $\mathrm{O}_{2}$ production rate and night net $\mathrm{O}_{2}$ consumption) to obtain the net productivity of the biofilm on a daily basis. At the end of each $24 \mathrm{~h}$ period, living nematodes of N-biofilms were counted under a stereoscopy microscope to determine their mortality during the experiment.

Six day incubation experiment. This experiment was designed to examine the influence of meiofaunal activity on steady-state oxygen turnover in cultivated diatom biofilms while taking into account the spatial heterogeneity of the biofilm. Measurements were carried out during 2 successive incubation periods (Periods 1 and 2) in August 2005 using biofilms cultivated with 1 mo old diatoms (Nitzschia palea and Fistulifera saprophila mixture). At Day 0, 1 treatment biofilm was amended with 300 nematodes (N-biofilm), 
while the control biofilm (C-biofilm) was not (Fig. 1). Then, $\mathrm{N}$ - and C-biofilms were incubated for $6 \mathrm{~d}$ at $18^{\circ} \mathrm{C}$ and under $35 \mu \mathrm{mol}$ photons $\mathrm{m}^{-2} \mathrm{~s}^{-1}$ light exposure. Measurements of oxygen concentration profiles were performed at Day 0 (prior to the introduction of nematodes in the N-biofilm) and at Day 6 ( $6 \mathrm{~d}$ of incubation). At Days 0 and 6, steady-state oxygen microprofiles were simultaneously measured in both $\mathrm{C}$ - and $\mathrm{N}$ biofilms, at 4 different random spots within each biofilm, to integrate the heterogeneity of the vertical distribution of oxygen in microbial biofilms (BuffanDubau et al. 2001) under light exposure of $70 \mu \mathrm{mol}$ photons $\mathrm{m}^{-2} \mathrm{~s}^{-1}$ and in the dark. The temperature reached 21 to $22^{\circ} \mathrm{C}$ during measurements. At the end of each incubation period, C-biofilm was weighed to measure the dry weight biomass of biofilms. Living meiofauna from $\mathrm{N}$-biofilms were enumerated under a stereomicroscope to examine mortality under experimental conditions.

Statistical analysis. For the short-term experiment, variability of the respective parameters was observed between the consecutively incubated and replicated biofilms (i.e. on the one hand, between the 3 control Cbiofilms and, on the other hand, between the 3 treatment N-biofilms). Consequently, each incubation was considered separately. For each incubation, values of net oxygen production rates and net oxygen consumption rates of each $\mathrm{N}$ and $\mathrm{C}$-biofilm were averaged over the daytime period and the night period, respectively (see 'Results'). In the same way, the maximum oxygen concentrations and the depths of the maximum oxygen concentrations were averaged over the light-exposed period. Consequently, the standard errors (SE) that are associated with these averages represent temporal variations in the respective parameters for each incubation (Table 1). The Student's $t$-test was used to compare average oxygen concentrations, net oxygen production and oxygen consumption between $\mathrm{C}$ - and $\mathrm{N}$-biofilms. Results for the $24 \mathrm{~h}$ experiment are shown in Table 1. For the $6 \mathrm{~d}$ experiment, net oxygen produc- tion rates measured at 4 different random spots $(n=4)$ within each biofilm were compared between $\mathrm{C}$ - and $\mathrm{N}$-biofilms using Student's $t$-test. Thus, the errors associated with these averages represent spatial variations in the studied parameter. When data did not meet the assumption of homogeneous variances, a Mann-Whitney non-parametric test for independent samples was applied.

\section{RESULTS}

\section{Short-term $(24 \mathrm{~h})$ experiment}

The thickness and area of diatom biofilms used in this experiment averaged $2 \pm 0.5 \mathrm{~mm}$ and $1.8 \pm 0.1 \mathrm{~cm}^{2}$, respectively, at $T_{0}$. At the end of the $24 \mathrm{~h}$ incubations, living nematodes (N-biofilms) represented 86 to $99.5 \%$ of the biofilm-dwelling meiofauna. Living nematode density was lower in the N3-biofilm (Period 3) compared to the N1- and N2-biofilms (Periods 1 and 2): 42 versus 103 and 139 ind. $\mathrm{cm}^{-2}$, respectively. This difference in nematode density was due to a difference in nematode mortality rates during the nycthemeral incubation periods: $93 \%$ versus 83 and $76.8 \%$ of mortality in N3-, N2- and N1-biofilms, respectively. Nematode mortality occurred within the first hours of incubations, likely resulting from stress linked to both handpicking and adaptation of nematodes to their new experimental conditions.

As expected, the maximum concentrations of oxygen microprofiles, linked to the photosynthetic activity of the $\mathrm{N}$ and $\mathrm{C}$ diatom biofilms, responded to nycthemeral variations in the irradiance during incubations (Fig. 2). During the light-exposed period (from 07:00 to 16:00 h), average maximum concentrations of oxygen microprofiles were significantly higher in N-biofilms than in C-biofilms for the first and the second nycthemeral incubation periods, while no difference was observed for the third period (Table 1, Fig. 3). For the

Table 1. Measurements (means $\pm \mathrm{SE}$ ) for the three $24 \mathrm{~h}$ nycthemeral incubation periods $(1,2$ and 3$)$. For each period SE values represent temporal variations of maximum $\mathrm{O}_{2}$ concentration $(\mathrm{n}=25)$, maximum depth $(\mathrm{n}=25)$, and net $\mathrm{O}_{2}$ production rate $(\mathrm{n}=34)$ during daytime and net $\mathrm{O}_{2}$ consumption rate $(\mathrm{n}=31)$ during the night. $\mathrm{p}$-values indicate the significance level for comparisons between $\mathrm{N}$-biofilms (containing nematodes) and C-biofilms (without meiofauna)

\begin{tabular}{|c|c|c|c|c|c|c|c|c|c|}
\hline Period & $\begin{array}{l}\text { Nematode } \\
\text { density } \\
\left(\text { ind. } \mathrm{cm}^{-2}\right)\end{array}$ & $\begin{array}{c}\mathrm{O}_{2} \\
\underset{(\mu \mathrm{M})}{\operatorname{maximum}}\end{array}$ & $\mathrm{p}$ & $\begin{array}{l}\text { Maximum } \\
\text { depth } \\
(\mu \mathrm{m})\end{array}$ & $\mathrm{p}$ & $\begin{array}{c}\text { Day net } \mathrm{O}_{2} \\
\text { production } \\
\left(\mathrm{nmol} \mathrm{O}_{2} \mathrm{~cm}^{-2} \mathrm{~min}^{-1}\right)\end{array}$ & $\mathrm{p}$ & $\begin{array}{c}\text { Night net } \mathrm{O}_{2} \\
\text { consumption } \\
\left(\mathrm{nmol} \mathrm{O} \mathrm{cm}^{-2} \mathrm{~min}^{-1}\right)\end{array}$ & $\mathrm{p}$ \\
\hline $1 \begin{array}{l}\mathrm{N} 1 \\
\mathrm{C} 1\end{array}$ & $\begin{array}{c}103 \\
0\end{array}$ & $\begin{array}{l}205 \pm 15 \\
111 \pm 14\end{array}$ & $<0.001$ & $\begin{aligned} 427 & \pm 70 \\
8 & \pm 8\end{aligned}$ & $<0.001$ & $\begin{array}{r}0.052 \pm 0.090 \\
-0.536 \pm 0.042\end{array}$ & $<0.001$ & $\begin{array}{l}-0.577 \pm 0.036 \\
-0.401 \pm 0.011\end{array}$ & $<0.001$ \\
\hline $\begin{array}{ll}2 & \mathrm{~N} 2 \\
\mathrm{C} 2\end{array}$ & $\begin{array}{c}139 \\
0\end{array}$ & $\begin{array}{l}398 \pm 33 \\
276 \pm 23\end{array}$ & $<0.01$ & $\begin{array}{l}656 \pm 79 \\
167 \pm 83\end{array}$ & $<0.001$ & $\begin{array}{r}0.341 \pm 0.142 \\
-0.184 \pm 0.084\end{array}$ & $<0.05$ & $\begin{array}{l}-0.564 \pm 0.169 \\
-0.454 \pm 0.113\end{array}$ & $<0.001$ \\
\hline $\begin{array}{ll}3 & \mathrm{~N} 3 \\
\mathrm{C} 3\end{array}$ & $\begin{array}{c}42 \\
0\end{array}$ & $\begin{array}{l}73 \pm 6 \\
69 \pm 5\end{array}$ & 0.57 & $\begin{array}{r}300 \pm 79 \\
93 \pm 32\end{array}$ & 0.42 & $\begin{array}{l}-0.022 \pm 0.038 \\
-0.050 \pm 0.036\end{array}$ & 0.59 & $\begin{array}{l}-0.109 \pm 0.007 \\
-0.317 \pm 0.024\end{array}$ & $<0.001$ \\
\hline
\end{tabular}


$24 \mathrm{~h}$ Nycthemeral Periods 1 and 2, it was also observed that the depth of these oxygen peaks was deeper in $\mathrm{N}$-biofilms than in C-biofilms (maximum depth, Table 1). On the whole, these results indicated that oxygenation of biofilms was improved in the presence of the nematode assemblage, during Periods 1 and 2, i.e. in the N-biofilms with both lower mortality rates and higher nematode densities (103 to 139 ind. $\mathrm{cm}^{-2}$ ).

Average net oxygen production rates were calculated for the day (daytime net $\mathrm{O}_{2}$ production, i.e. from 07:30 to 20:00 h) and the night periods (night $\mathrm{O}_{2}$ uptake rate) for each $24 \mathrm{~h}$ incubation period (Table 1). Average daytime net oxygen production rates were significantly higher in N-biofilms than in C-biofilms (Fig. 4) for Periods 1 and 2, while no difference was observed for Period 3 (Table 1). Further, average daytime net oxygen fluxes were positive in $\mathrm{N}$-biofilms for Periods 1 and 2, while they were negative in C-biofilms and in N-biofilm for Period 3 (Table 1). Hence, for Periods 1 and 2, the biofilms that contained nematodes produced net positive fluxes of oxygen in the daytime and, thus, were acting as a source of oxygen (net

Oxygen concentration $(\mu \mathrm{M})$
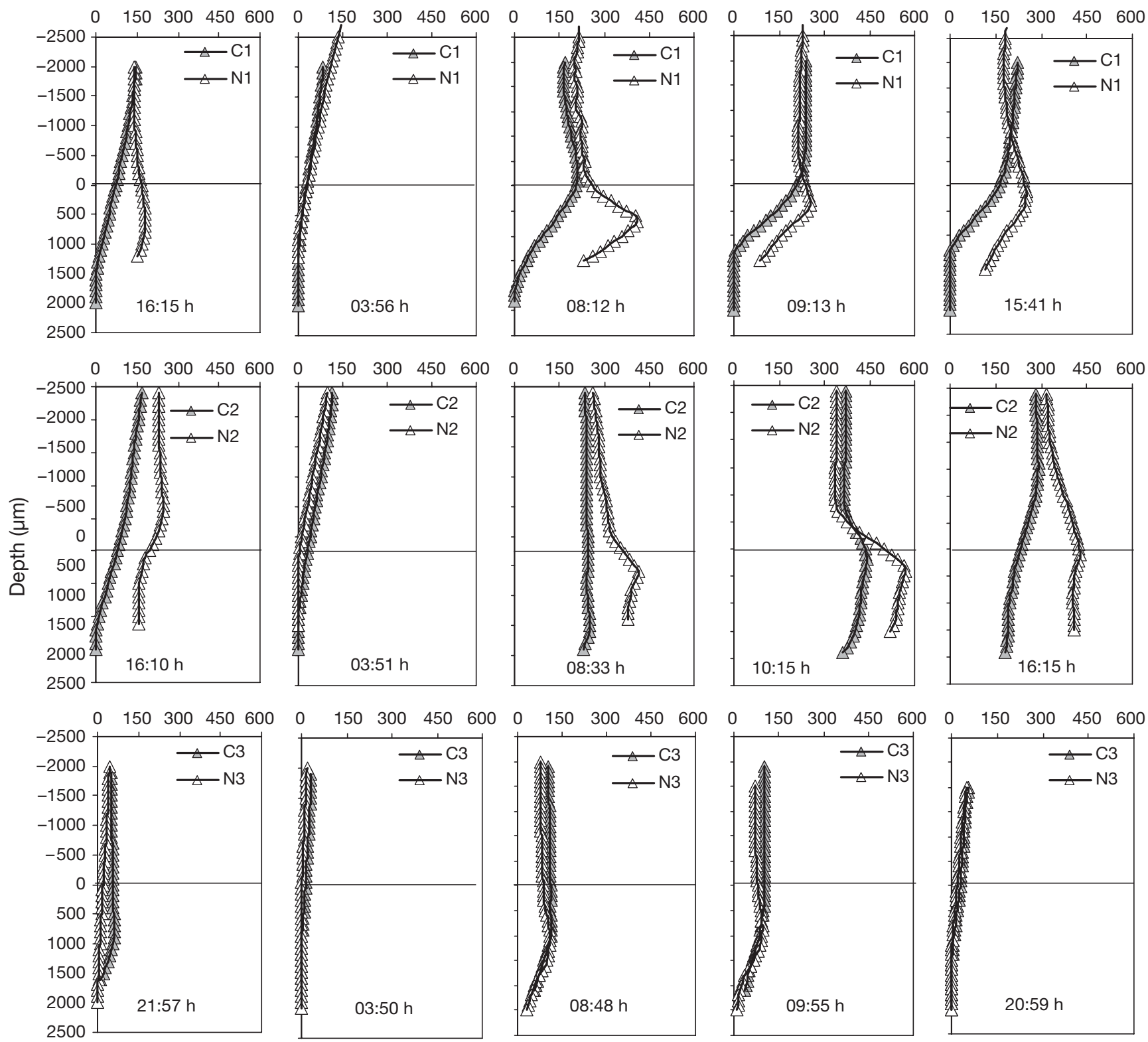

Fig. 3. Short-term $(24 \mathrm{~h})$ experiment. Oxygen microprofiles simultaneously measured in both N-biofilms (with nematodes) and C-biofilms (without meiofauna) for selected times of the $24 \mathrm{~h}$ nycthemeral incubation periods $(1,2$ and 3$)$. $0 \mu \mathrm{m}$ depth: the biofilm/liquid medium interface; positive values: depths in the biofilm; negative values: depths in the overlaying liquid medium 

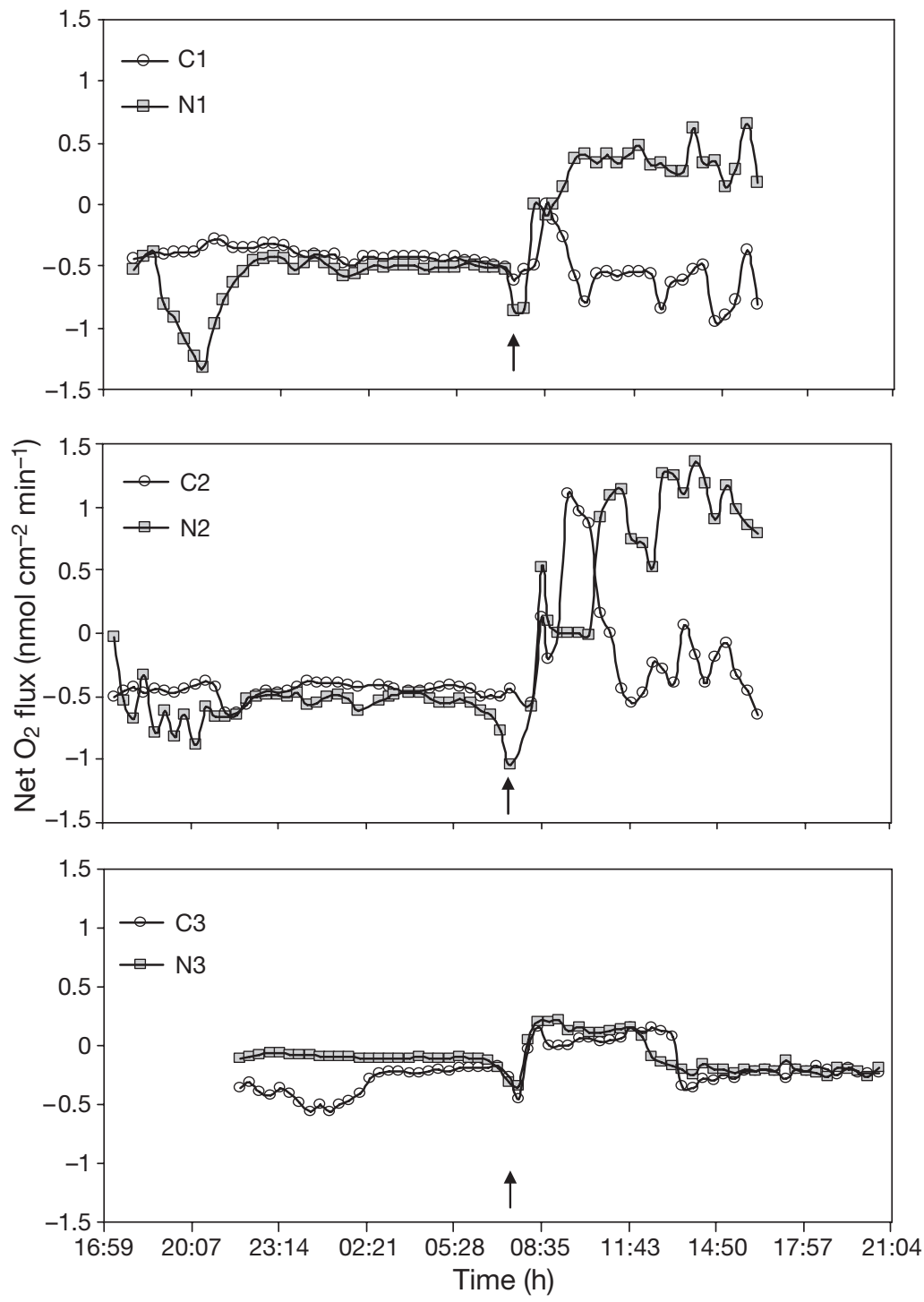

Fig. 4. Short-term $(24 \mathrm{~h})$ experiment. Net oxygen fluxes versus time for both $\mathrm{N}$ biofilms (with nematodes; 103, 139 and 42 ind. $\mathrm{cm}^{-2}$ in N1, N2 and N3, respectively) and C-biofilms (without meiofauna) during the $24 \mathrm{~h}$ nycthemeral incubation periods (1,2 and 3 ). A positive flux indicates a net production of oxygen, whereas a negative flux indicates a consumption of oxygen by the diatom biofilms. Arrows designate the time of sunrise

autotrophic), while, in contrast, C-biofilms (without nematodes) were acting as a sink for oxygen (respiration exceeded photosynthetic oxygen production, i.e. net heterotrophic). This indicates that net oxygen production of diatom biofilms was stimulated in the presence of nematodes during Periods 1 and 2, i.e. in biofilms with both lower mortality rates and higher nematode densities (103 to 139 ind. $\mathrm{cm}^{-2}$ ).

Average net oxygen consumption rates in the dark were significantly higher in N-biofilms than in Cbiofilms for Periods 1 and 2 (Table 1). Assuming that the difference in oxygen consumption rates between $\mathrm{N}$ - and C-biofilms was mainly attributed to nematode respiration, it was estimated that average respiration rates of nematodes ranged between $0.0985 \pm 0.0245$ and $0.0473 \pm$ $0.0078 \mathrm{nmol} \mathrm{O}_{2}$ ind. $^{-1} \mathrm{~h}^{-1}$ for the $24 \mathrm{~h}$ Periods 1 and 2, respectively. Results differed during Period 3 (Table 1), which was likely related to the lower density of living nematodes observed in the N3-biofilm compared to those in both N1- and N2-biofilms.

\section{Six day incubation experiment}

At the beginning of this experiment, the thickness of diatom biofilms varied from 2.5 to $3 \mathrm{~mm}$ (sides) to $4 \mathrm{~mm}$ (centre). Biofilm area averaged $0.7 \pm 0.2 \mathrm{~cm}^{2}$. The biomass of C-biofilms averaged $28.76 \pm$ $5.85 \mathrm{mg} \mathrm{cm}^{-2}$ (dry weight) at Day 6. At the end of incubation periods, the density of living nematodes and rotifers (mainly of the classes Bdelloidea and Monogononta, genus Cephalodella) averaged $192 \pm 18$ and $164 \pm 67$ ind. $\mathrm{cm}^{-2}$, respectively, in N-biofilms. Rotifers and, particularly, monogononts are characterised by relatively short life cycles (several days) and short egg development periods (hours; Ricci \& Balsamo 2000). Thus, it is likely that rotifers developed during the $6 \mathrm{~d}$ incubations.

Average net oxygen production in the photic zone, measured at the end of the $6 \mathrm{~d}$ incubations (Day 6) under constant artificial light regime, was significantly higher in N-biofilms than in C-biofilms $(\mathrm{p}<0.01)$ for both periods (Fig. 5) $-4.35 \pm$ 0.34 and $7.57 \pm 0.91 \mathrm{nmol} \mathrm{O}_{2} \mathrm{~cm}^{-2} \mathrm{~min}^{-1}$ in N1- and N2-biofilms, respectively, versus $3.42 \pm 0.37$ and $5.75 \pm 0.22 \mathrm{nmol} \mathrm{O}_{2} \mathrm{~cm}^{-2}$ $\mathrm{min}^{-1}$ in $\mathrm{C} 1$ - and $\mathrm{C} 2$-biofilms, respectively-whereas at Day 0 no significant difference was observed between N- and C-biofilms (Fig. 5). Dark oxygen consumption rates were not significantly different between $\mathrm{C}$ - and N-biofilms, averaging $-0.0196 \pm 0.0030$ and $-0.0237 \pm 0.0035 \mathrm{nmol} \mathrm{O}_{2} \mathrm{~cm}^{-2} \mathrm{~s}^{-1}$ at Days 0 and 6, respectively.

\section{DISCUSSION}

Overall, this study provided evidence that nematode activity may influence the oxygen dynamics of diatom biofilms. These effects might be dependent on the 


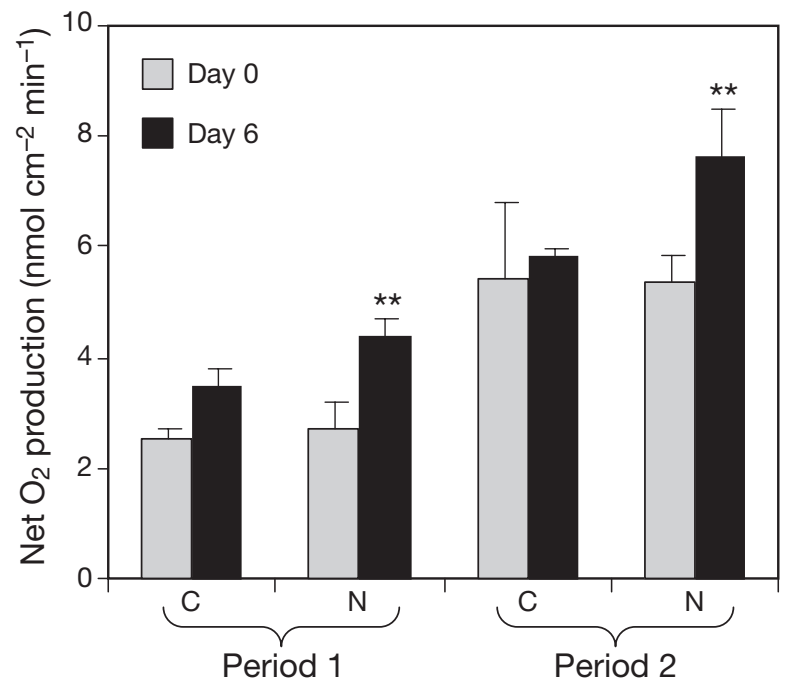

Fig. 5. Six day experiment. Average net oxygen production $(\mathrm{n}=4$, mean $\pm \mathrm{SD}$ ) in the photic zone of both N-biofilms (with meiofauna) and C-biofilms (without meiofauna), calculated for the 2 successive $6 \mathrm{~d}$ incubation periods, at Day 0 (beginning of the experiment) and at Day 6 (6 d of incubation). ${ }^{* *} \mathrm{p}<0.01$

densities of nematodes. In the present study, significant effects were observed at nematode densities exceeding 100 ind. $\mathrm{cm}^{-2}$, but not at a density of $<50$ ind. $\mathrm{cm}^{-2}$. Although these results issued from experimental measurements in artificial biofilms, nematode densities were in the range of those reported for lotic environments: from approximately 50 to 500 ind. $\mathrm{cm}^{-2}$ in freefloating mats in the Llobregat River, Spain (Sabater et al. 2003), and from $16 \pm 1.5$ to $145 \pm 30$ ind. $\mathrm{cm}^{-2}$ in epilithic biofilm of the Garonne River (E. Buffan-Dubau unpubl. data). Thus, in rivers, biofilm-dwelling nematodes may reach density values that could influence the microdistribution and net production of oxygen in diatom aggregates. Future experiments are needed to determine potential effective threshold values of nematode densities in microalgal biofilms.

The concentrations of oxygen peaks were both higher and located deeper in the diatom biofilms with nematodes than in the corresponding control biofilms during the $24 \mathrm{~h}$ nycthemeral incubation periods. Generally, the oxygen peak depth approximately corresponds to the depth of the gross photosynthesis peak in phototrophic biofilms (e.g. Epping et al. 1999, BuffanDubau et al. 2001). Thus, it is likely that the maximum photosynthetic activity occurred deeper in diatom biofilms with nematodes. One of the most important factors controlling the vertical distribution of photosynthesis in benthic environments is the light intensity available at a given depth (Whitney \& Darley 1983). Underwood et al. (2005) suggested that benthic microalgae have adapted to fill light-related niches within biofilms, using both migratory behaviours and physiological regulations. Further, Aller \& Aller (1992) sug- gested that meiofaunal activity was involved in the increase of porosity of marine mud. By foraging on diatoms in the top layer, the nematodes may relieve the self-shading that limits productivity in the deeper layers of the biofilm and thus contribute to enhancing light penetration in the biofilm. Alternatively, the burrowing activity of nematodes might have enhanced light penetration by modifying the biofilm porosity and spatial arrangement of the diatoms within the biofilms. Both phenomena might explain the deeper location of the oxygen peaks that we observed in diatom biofilms with nematodes.

Average daytime net oxygen production rates were higher in biofilms with meiofauna than in control biofilms during the $24 \mathrm{~h}$ nycthemeral incubation periods. This difference was also observed for steady-state biofilms during the $6 \mathrm{~d}$ incubation experiment. Kaehler \& Froneman (2002), measuring $\left[{ }^{14} \mathrm{C}\right]$ sodium bicarbonate incorporation of marine biofilms, previously determined that grazing by macrofauna (Nodilittorina africana) can increase the photosynthetic capacity (production $\mathrm{\mu g}^{-1}$ chlorophyll a) of microalgae. In littoral habitats, interactions between herbivore macrofauna and biofilm microalgae are known to influence primary productivity (Liess \& Hillebrand 2004). Our data suggest that such effects might also result from the interactions between the meiobenthic nematodes and diatom biofilms.

It can be envisaged that meiofaunal activity could have enhanced net oxygen production of the cultivated diatom biofilms by a number of mechanisms. Firstly, as suggested before, bioturbation and particle reworking by nematode activities could have increased porosity, enhancing light penetration and facilitating nutrient supply to microalgae. Secondly, meiofauna excrete metabolic wastes containing nitrogen and phosphorus, which may be limiting in natural environments (Hakenkamp \& Morin 2000). During the experimental incubations, the medium was frequently renewed to keep nutrient concentration in excess; thus, it is unlikely that meiofaunal excretion influenced the production of diatom biofilms. On the other hand, it has been previously shown that nematodes may affect bacterial activity in basically similar ways as those in which they may affect microalgal biofilm activity: overgrazing may induce a decrease (De Mesel et al. 2003), whereas moderate grazing and bioturbation can increase bacterial activity (Alkemade et al. 1992, Traunspurger et al. 1997). Thus, 2 additional scenarios can be envisaged. Nematodes could have contributed to enhance net oxygen production of the cultivated diatom biofilms by bacterial overgrazing or, alternatively, nematodes could have stimulated bacterial respiration by moderate grazing or bioturbation. The latter alternative might indicate that the detected 
effect of nematodes on net oxygen production by diatoms in the present study may have been more pronounced, but partly masked, by a potential stimulation of respiration of the bacterial community of the biofilms.

Respiration rates of nematodes were estimated from the observed differences in oxygen consumption in the dark between $\mathrm{N}$ - and $\mathrm{C}$-biofilms, thus assuming that the nematodes themselves did not influence the respiration rates of the microbial communities. This calculation provided values that are in the range of those previously reported in the literature for a widely distributed freshwater species, Tobrilus gracilis Bastian (from 0.00417 to $0.0833 \mathrm{nmol} \mathrm{O}{ }_{2}$ ind. ${ }^{-1} \mathrm{~h}^{-1}$; Schiemer \& Duncan 1974), and for soil-inhabiting nematodes (from 0.052 to $0.367 \mathrm{nmol} \mathrm{O}_{2}$ ind..$^{-1} \mathrm{~h}^{-1}$ at $20^{\circ} \mathrm{C}$; Klekowski et al. 1972). However, it is possible that the differences in oxygen consumption in the dark between $\mathrm{N}$ - and $\mathrm{C}$ biofilms did not only result from nematode respiration, but also from changes in bacterial respiration rates. Moreover, it has been reported that daytime photosynthesis leads to accumulation of labile organic carbon, which is then respired during night time, and, consequently, night time biofilm respiration is correlated to daytime photosynthesis (e.g. Epping \& Kühl 2000). Since, in the present study, photosynthetic activity was higher in N-biofilms, it is possible that the temporal coupling between photosynthesis and respiration could have led to intensified respiration in the biofilms with nematodes. However, this hypothesis of a potential temporal coupling is not supported by results from the $6 \mathrm{~d}$ experiment, indicating that oxygen consumption rates in the dark did not differ between $\mathrm{N}$ - and C-biofilms at the end of the incubation period.

The short-term experiment simulates the disturbance of a lotic diatom biofilm as would be induced by a sudden colonisation of nematode populations. This disturbance resulted in an increase of the net productivity of the biofilm, which can be related to the phenomena described above. In the natural lotic environment such a disturbance created by a rapid invasion of the biofilm by nematode populations may represent a regularly occurring phenomenon. Indeed, after periodic disturbances such as spates, which severely reduce or eliminate the meiofaunal community, meiofaunal recolonisation at the patch scale is rapid (Robertson 2000). The question remains whether the long-term occurrence of nematodes in the biofilm would also result in an increased productivity rate. So far, this has not been experimentally tested. A first indication of a persistent increase of net productivity related to the continuous presence of nematodes is, however, provided by the $6 \mathrm{~d}$ incubation experiment.

One aspect that particularly distinguishes the present work from most previous studies of meiofaunal relationships with microalgal resources is that the oxygen production rates of diatom biofilms were measured from microprofiles, providing analyses of the vertical distribution of oxygen through biofilms (Revsbech et al. 1983). In contrast, most previous studies have relied on ${ }^{14} \mathrm{C}$-based estimates of oxygen primary production, which may underestimate photosynthetic rates of benthic microalgae due to the difficulty in measuring the ${ }^{14} \mathrm{C}$-specific activity of the porewater in the sediment photic zone (Vadeboncoeur \& Lodge 1998). In addition, the microsensor-based measurements also allow the collection of more detailed spatial information, such as the depth of the oxygen maximum and oxygen penetration depths. Such information relates to the dynamics of the biofilm and may also provide clues on bioturbation and reshuffling of the phototrophic cells, in addition to the effect of meiobenthic grazing per se. Hence, microelectrode analyses may be helpful in unravelling the different mechanisms acting in biofilms that can be attributed to the meiofauna. To our knowledge, there has only been 1 previous study of meiofaunal-microalgal interactions with the use of microelectrodes to measure the production rates of benthic microalgae. Pinckney et al. (2003) observed that the turnover rate of benthic microalgae at an estuarine intertidal site was higher under conditions of high grazing rates, suggesting a compensatory response of benthic microalgae to grazing pressure.

Several authors have suggested that nematodes affect stream biofilm through bioturbation and grazing; however, knowledge of their feeding behaviour and their trophic role is poor, since most studies have been carried out in marine environments (exceptions are Traunspurger 2000, Höckelmann et al. 2004). Within nematode communities, all trophic resources are utilised. Microscopic inspection of their buccal cavity indicated that the nematodes used in the present study were deposit feeders (or swallowers) and epistrate feeders (or tear and swallow feeders), i.e. they could feed on bacteria, diatoms and other unicellular eukaryotes that are swallowed whole or torn (Moens et al. 2006). Microscopic observations also indicated that nematode guts were full, suggesting that nematodes fed on bacteria and/or diatoms (but intact frustules were not observed) during the experimental incubations. However, our study did not allow the separation of grazing effects and the effects of bioturbation (i.e. burrowing of nematodes through the diatom biofilms).

The relationships between microalgae and meiofauna are complex, with linked feed-back mechanisms that operate over small spatio-temporal scales (BuffanDubau \& Carman 2000). This study using experimental biofilms and the oxygen micrelectrode method to measure oxygen microdistribution simultaneously in the presence and absence of meiofauna has provided reliable information, indicating that nematode activity 
could influence the oxygen metabolism of diatom biofilms. Further, results support the hypothesis that, in addition to their top-down control function, meiofauna may play a secondary role by modifying the potential bottom-up controls through alterations in the light environment and the enhancement of solute transport rates, as has been suggested by Pinckney et al. (2003). As a matter of fact, this study may contribute to a better understanding of the relationships between microalgal biofilms and their meiofaunal community.

Acknowledgements. We thank O. Pringault for his assistance with the $\mathrm{O}_{2}$ microelectrode method and $\mathrm{F}$. Azemar for the determination of rotifer taxa. This study was partly funded by the French national network on biofilm research (BIOFILMSPNIR).

\section{LITERATURE CITED}

Alkemade R, Wielemaker A, de Jong SA, Sandee AJJ (1992) Experimental evidence for the role of bioturbation by the marine nematode Diplolaimella dievengatensis in stimulating the mineralization of Spartina anglica detritus. Mar Ecol Prog Ser 90:149-155

Aller RC, Aller JY (1992) Meiofauna and solute transport in marine muds. Limnol Oceanogr 37:1018-1033

Alvarez M, Peckarsky BL (2005) How do grazers affect periphyton heterogeneity in streams? Oecologia 142:576-587

Battin TJ, Kaplan LA, Newbold JD, Hansen CME (2003) Contributions of microbial biofilms to ecosystem processes in stream mesocosms. Nature 426:439-442

Biggs BJF (1995) The contribution of flood disturbance, catchment geology and land use to the habitat template of periphyton in stream ecosystems. Freshw Biol 33:419-438

Borchardt MA, Bott TL (1995) Meiofaunal grazing of bacteria and algae in a Piedmont stream. J N Am Benthol Soc 14: 278-298

Bott TL, Borchardt MA (1999) Grazing of protozoa, bacteria, and diatoms by meiofauna in lotic epibenthic communities. J N Am Benthol Soc 18:499-513

Buffan-Dubau E, Carman KR (2000) Diel feeding behavior of meiofauna and their relationships with microalgal resources. Limnol Oceanogr 45:381-395

Buffan-Dubau E, Pringault O, de Wit R (2001) Artificial coldadapted microbial mats cultured from Antarctic lake samples. 1. Formation and structure. Aquat Microb Ecol 26: 115-125

De Mesel I, Derycke S, Swings J, Vincx M, Moens T (2003) Influence of bacterivorous nematodes on the decomposition of cordgrass. J Exp Mar Biol Ecol 296: 227-242

Epping EHG, Kühl M (2000) The response of photosynthesis and oxygen consumption to short-term changes in temperature and irradiance in a cyanobacterial mat (Ebro Delta, Spain). Environ Microbiol 2:465-474

Epping EHG, Khalili A, Thar R (1999) Photosynthesis and the dynamics of oxygen consumption in a microbial mat as calculated from transient oxygen microprofiles. Limnol Oceanogr 44:1936-1948

Garcia H, Gordon LI (1992) Solubility of oxygen at different temperature and salinity. Limnol Oceanogr 37:1307-1312

Glud RN, Ramsing BN, Revsbech PN (1992) Photosynthesis and photosynthesis-coupled respiration in natural biofilms quantified with oxygen microsensors. J Phycol 28:51-60
Glud RN, Gundersen JK, Revsbech NP, Jørgensen BB (1994) Effects on the benthic diffusive boundary layer imposed by microelectrodes. Limnol Oceanogr 39:462-467

Hakenkamp CC, Morin A (2000) The importance of meiofauna to lotic ecosystem functioning. Freshw Biol 44:165-175

Hann BJ (1991) Invertebrate grazers-periphyton interactions in a eutrophic marsh pond. Freshw Biol 26:87-96

Hill WR (1996) Effects of light. In: Stevenson RJ, Bothwell ML, Lowe RL (eds) Algal ecology. Freshwater benthic ecosystems. Academic Press, San Francisco, CA, p 121-148

Hillebrand H, Sommer U (1997) Response of epilithic microphytobenthos of the western Baltic Sea to in situ experiments with nutrient enrichment. Mar Ecol Prog Ser 160: $35-46$

Höckelmann C, Moens T, Jüttner F (2004) Odor compounds from cyanobacterial biofilms acting as attractants and repellents for free-living nematodes. Limnol Oceanogr 49:1809-1819

Hodda M, Eyualem-Abebe E (2006) Techniques for processing freshwater nematodes. In: Abebe E, Andrássy I, Traunspurger W (eds) Freshwater nematodes: ecology and taxonomy. CABI publishing, Cambridge, p 31-45

Kaehler S, Froneman PW (2002) Herbivore-mediated increase in the photosynthetic capacity of marine biofilms: indirect effects of changing microalgal assemblage composition. Mar Ecol Prog Ser 234:15-22

Kilham SS, Kreeger DA, Lynn SG, Goulden CE, Herrera L (1998) COMBO: a defined freshwater culture medium for algae and zooplankton. Hydrobiologia 377:147-159

Klekowski RZ, Wasilewska L, Paplinska E (1972) Oxygen consumption by soil-inhabiting nematodes. Nematologica 19:391-403

Kühl M, Glud NR, Ploug H, Ramsing BN (1996) Microenvironmental control of photosynthesis and photosynthesiscoupled respiration in an epilithic cyanobacterial biofilm. J Phycol 32:799-812

Lawrence JR, Scharf B, Packroff G, Neu TR (2002) Microscale evaluation of the effects of grazing by invertebrates with contrasting feeding modes on river biofilm architecture and composition. Microb Ecol 43:199-207

Liess A, Hillebrand H (2004) Direct and indirect effects in herbivore-periphyton interactions. Arch Hydrobiol 159: 433-453

Moens T, Bergtold M, Traunspurger W (2006) Feeding ecology of free-living benthic nematodes In: Abebe E, Andrássy I, Traunspurger W (eds) Freshwater nematodes: ecology and taxonomy. CABI publishing, Cambridge, p 105-131

Peterson CG (1996) Response of benthic algal communities to natural physical disturbances. In: Stevenson RJ, Bothwell ML, Lowe RL (eds) Algal ecology-freshwater benthic ecosystems. Academic Press, San Diego, CA, p 57-72

Pinckney JL, Carman KR, Lumsden SE, Hymel SN (2003) Microalgal-meiofaunal trophic relationships in muddy intertidal estuarine sediments. Aquat Microb Ecol 31: 99-108

Revsbech NP (1989) An oxygen microsensor with a guard cathode. Limnol Oceanogr 34:474-478

Revsbech N, Jørgesen BB, Blackburn TH (1983) Microelectrode studies of the photosynthesis and $\mathrm{O}_{2}, \mathrm{H}_{2} \mathrm{~S}$, and $\mathrm{pH}$ profiles of a microbial mat. Limnol Oceanogr 28: 1062-1074

Ricci C, Balsamo M (2000) The biology and ecology of lotic rotifers and gastrotrichs. Freshw Biol 44:15-28

Robertson AL (2000) Lotic meiofaunal community dynamics: colonisation, resilience and persistence in a spatially and temporally heterogeneous environment. Freshw Biol 44: 135-147 
Robertson AL, Rundle SD, Schmid-Araya JM (2000) An introduction to a special issue on lotic meiofauna. Freshw Biol $44: 1-3$

Sabater S, Vialata E, Gaudes A, Guasch H, Munoz I, Romani A (2003) Ecological implications of mass growth of benthic cyanobacteria in rivers. Aquat Microb Ecol 32:175-184

Schiemer F, Duncan A (1974) The oxygen consumption of a freshwater benthic nematode Tortilus gracilis (Bastian). Oecologia 15:121-126

Schmid-Araya JM, Schmid PE (2000) Trophic relationships: integrating meiofauna into a realistic benthic food web. Freshw Biol 44:149-163

Schmid-Araya JM, Hildrew AG, Robertson A, Scmid PE, Winterbottom J (2002) The importance of meiofauna in food webs: evidence from an acid stream. Ecology 83:1271-1285

Sibert JR, Brown TJ, Healey MC, Kask BA, Nauman RJ (1977) Detritus based food web: exploitation by juvenile chum salmon (Onchorhynchus keta). Science 196:649-650

Stead TK, Schmid-Araya JM, Hildrew AG (2005) Secondary production of a stream metazoan community: Does the meiofauna make a difference? Limnol Oceanogr 50:398-403

Editorial responsibility: Antje Boetius, Bremen, Germany
Traunspurger W (2000) The biology and ecology of lotic nematodes. Freshw Biol 44:29-45

Traunspurger W, Bergtold M, Goedkoop W (1997) The effects of nematodes on bacterial activity and abundance in a freshwater sediment. Oecologia 112:118-122

Underwood GJC, Perkins RG, Consalvey MC, Hanlon ARM, Oxborough K, Baker NR, Paterson DM (2005) Patterns in microphytobenthic primary productivity: species-specific variation in migratory rhythms and photosynthetic efficiency in mixed-species biofilms. Limnol Oceanogr 50: 755-767

Vadeboncoeur Y, Lodge DM (1998) Dissolved inorganic carbon sources for epipelic algal production: sensitivity of primary production estimates to spatial and temporal distribution of ${ }^{14} \mathrm{C}$. Limnol Oceanogr 43:1222-1226

Whitney DE, Darley MW (1983) Effect of light intensity upon salt marsh benthic microalgal photosynthesis. Mar Biol 75: $249-252$

Wieland A, Beer D, Damgaard L, Kühl M, Dusschoten D, As H (2001) Fine-scale measurement of diffusivity in a microbial mat with nuclear magnetic resonance imaging. Limnol Oceanogr 46:248-259

Submitted: February 7, 2007; Accepted: September 18, 2007 Proofs received from author(s): November 8, 2007 